\title{
KARAKTERISTIK BIOINDIKATOR CISADANE : KAJIAN PEMANFAATAN MAKROBENTIK UNTUK MENILAI KUALITAS SUNGAI CISADANE
}

\section{CISADANE BIOINDICATOR CHARACTERISTICS: STUDY TO ASSESS THE CISADANE QUALITY OF USE MACROZOOBENTHOS}

\author{
Sri Unon Purwati ${ }^{11}$
}

(Diterima tanggal 09-03-2015; Disetujui tanggal 15-02-2016)

\begin{abstract}
ABSTRAK
Biomonitoring dilakukan untuk mengevaluasi kondisi badan air dalam ekosistem akuatik dengan memanfaatkan bioindikator sebagai tolak ukurnya. Bioindikator yang sering digunakan adalah makroinvertebrata yang hidup menetap di dasar sungai yang dengan karakteristiknya dapat mengindikasikan kualitas lingkungan badan air tempat mereka hidup. Pemantauan kualitas Sungai Cisadane dengan memanfaatkan bioindikator makroinvertebrata dilakukan pada tahun 2003-2007,2010 dan 2013 di beberapa titik yang mewakili segmen hulu (C01-Muara Jaya),tengah (C05-Karya Bhakti; C06-Jasmin) dan hilir (C22-Kali Baru). Pendekatan menggunakan Indeks keanekaragaman (Diversity Indices) dan pendekatan indeks biologi (Biotic Indices). Status kualitas air sungai Cisadane dari hulu sampai hilir berdasarkan karakteristik Makroinvertebrata berada pada kondisi sedang sampai buruk. Status ini diperoleh melalui penggabungan hasil perhitungan H', prosen (\%) EPT dan ASPT. Serta data pendukung hasil analisis parameter kimia DO,BOD, $\mathrm{COD}, \mathrm{NO}_{3}$ dan TSS. Daerah hulu Cisadane dicirikan oleh Ordo Ephemeroptera, Familia Lepthophlebidae, Genus Paraleptoplebia, Spesies $P$. submarginata dan $P$. cinca. Daerah tengah Cisadane dengan dominan limbah domestik dicirikan oleh Ordo Ephemeroptera, Familia Baetidae, Genus Baetis, Spesies B. Niger dan Ordo Trichoptera, Familia Hydropsychidae, Genus Hydropsyche, Spesies H. siltalai dan H. anguistipennis. Sedangkan daerah hilir Cisadane dicirikan oleh Class Oligochaeta, Familia Haplotaxidae dan Cacing Tubifisidae.

Kata Kunci: Biomonitoring, makroinvertebrata, kualitas Cisadane Indeks keanekaragaman (Diversity Indices), pendekatan indeks biologi (Biotic Indices), parameter kimia, .
\end{abstract}

\begin{abstract}
The biomonitoring conducted to evaluate the condition of water bodies in aquatic ecosystems by utilizing bioindicators as a starting measuring. Bio-indicator that is often used is macroinvertebrates that live settle in the riverbed which can indicate environmental quality characteristics of water bodies where they live. Cisadane river quality monitoring by utilizing bio-indicators of macroinvertebrates was carried out in 2003 to 2007. 2010 and 2013 at some point representing the upstream segment (C01-Muara Jaya), middle (C05-Karya Bhakti; C06-Jasmin) and downstream (C22-Kali Baru). The approach used diversity index (Diversity Indices) and the biological index (Biotic Indices).Based on the charakteristics of macroinvertebrate, state of Cisadane river water quality from upstream to downstream macroinvertebrate are in moderate to poor condition. This status is obtained by combining the results of the calculation $H$ ', per cent (\%) EPT and ASPT. As well as supporting data as the results of the analysis of chemical parameters DO, BOD, COD, NO3 and TSS. Cisadane upstream areas are characterized by the Order Ephemeroptera, Familia Lepthophlebidae, Paraleptoplebia Genus, Species P. submarginata and P. cinca. Cisadane central area which dominant domestic waste is characterized by the Order Ephemeroptera, Familia Baetidae, Baetis genus, species B. Niger and the Order Trichoptera, Familia Hydropsychidae, Hydropsyche Genus, Species H. siltalai and H. anguistipennis. While the downstream region Cisadane characterized by Class Oligochaeta, Familia Haplotaxidae and worms Tubifisidae.
\end{abstract}

Keywords: Biomonitoring, makroinvertebrate, quality of Cisadane, Diversit Indices, Biotic Indices, chemical parameters

Puslitbang Kualitas dan Laboratorium Lingkungan, Kaw. Puspiptek, Gd.210, Serpong, Prov. Banten.

Ph./Fax : +62 (021) 7560983, unon.purwati@gmail.com. 


\section{PENDAHULUAN}

Sungai sebagai perairan ekosistem terbuka yang sering juga disebut sebagai perairan umum sangat dipengaruhi oleh lingkungan sekitarnya [2]. Perubahan kondisi kualitas air pada aliran sungai merupakan dampak dari buangan dari penggunaan lahan yang ada. Perubahan pola pemanfaatan lahan pertanian, tegalan dan pemukiman serta meningkatnya aktivitas industri akan memberikan dampak terhadap kondisi hidrologis dalam suatu Daerah Aliran Sungai. Selain itu, berbagai aktivitas manusia dalam memenuhi kebutuhan hidupnya yang berasal dari kegiatan industri, rumah tangga dan pertanian akan menghasilkan limbah yang memberi sumbangan pada penurunan kualitas air sungai [3].

Sungai Cisadane merupakan sungai besar yang melintasi Provinsi Jawa Barat dan Banten. Sungai ini memiliki fungsi dan nilai yang sangat tinggi bagi kehidupan manusia dan kehidupan liar. Secara umum, kualitas air Sungai Cisadane semakin ke hilir semakin menurun dengan tingkat pencemaran semakin tinggi. Sumber pencemaran dari berbagai aktivitas di DAS Cisadane berasal dari rumah tangga, pertanian dan industri. Kualitas air Sungai Cisadane dari hulu hingga hilir yaitu tercemar ringan dan tercemar berat [4]. Dampak langsung dari pencemaran air serta rusaknya lingkungan perairan Sungai Cisadane dan anak-anak terlihat pada berkurangnya jumlah ikan asli sebanyak 75,6\% [2].

Indikator atau tanda bahwa air lingkungan telah tercemar adalah adanya perubahan atau tanda yang dapat diamati dan dapat digolongkan menjadi tiga [5]:

Pengamatan secara fisis, yaitu pengamatan pencemar air berdasarkan tingkat kejernihan air (kekeruhan), perubahan suhu, dan adanya perubahan warna, bau dan rasa.

Pengamatan secara kimiawi yaitu pengamatan pencemar air berdasarkan zat kimia yang terlarut dan perubahan $\mathrm{pH}$. Limbah domestik mempunyai karakteristik antara lain kekeruhan, TSS, BOD, DO, COD dan parameter Coliform. Kelompok bakteri Coliform merupakan salah satu indikator adanya kontaminan limbah domestik dalam perairan [3].

Pengamatan secara biologis yaitu pengamatan pencemar air berdasarkan mikroorganisme yang ada dalam air,terutama ada tidaknya bakteri pathogen.

Biomonitoring merupakan aplikasi ilmu pengetahuan biologi dalam ekosistem akuatik untuk mengevaluasi kondisi badan air. Biomonitoring didefinisikan sebagai : “ Organisme air tawar yang mencerminkan kualitas badan air dan dengan demikian dapat digunakan untuk memantau perubahan kesehatan ekosistem" [7].

Bioindikator adalah kelompok atau komunitas organisme yang kehadirannya atau perilakunya di alam berkorelasi dengan kondisi lingkungan, sehingga dapat digunakan sebagai petunjuk kualitas lingkungan. Sebuah bioindikator yang "ideal" setidaknya harus memiliki karakteristik sebagai berikut: (a) kesederhanaan taksonomi (mudah dikenali oleh nonspesialis); (b) berdistribusi lebar; (c) mobilitas rendah (indikasi lokal); (d) memiliki karakteristik ekologi yang jelas diketahui; (e) melimpah dan dapat dihitung; (f) dapat dilakukan analisis di laboratorium; (g) sensitivitas tinggi terhadap tekanan lingkungan; (h) memiliki kemampuan untuk dikuantifikasi dan distandardisasi [8]. 
Biomonitoring adalah metode mengamati dampak dari faktor eksternal pada ekosistem atau penggunaan sistematis organisme hidup atau respon mereka untuk menentukan kondisi atau perubahan lingkungan " [8]

Keberadaan makrobentik di ekosistem sangat penting artinya, karena berfungsi sebagai sumber pakan alami bagi ikan maupun predator lainnya dan berperan dalam proses perombakan materi organik. Fauna makrobentik layak digunakan sebagai bioindikator akuatik karena memiliki diversitas yang tinggi jika dibandingkan dengan komunitas biotik lainnya, relatif sesil sehingga mampu mencerminkan kondisi kualitas perairan yang ada, mudah dilakukan sampling dari lapangan, dan relatif sensitif atau toleran terhadap berbagai macam polutan $[8,9]$. Makrobentik digunakan sebagai bioindikator di dalam biomonitoring ekosistem sungai dengan berbagai tipe tekanan atau gangguan seperti polutan organik, logam berat, degradasi hydromorphologi, pengkayaan nutrisi, asidifikasi dan tekanan pada umumnya [8].

Sebagian besar standar nasional yang digunakan untuk menilai kualitas air menggunakan indikator fisika dan kimia yang berhubungan dengan polutan dan gangguan khusus. Namun, komunitas biologi merefleksikan tidak hanya kondisi sumber daya akuatik saat ini tetapi juga perubahan kondisi dalam waktu lama dan dampak dari beberapa gangguan, pada banyak standar nasional tersebut hanya bakteria Coliform yang digunakan sebagai indikator biologi [10]. Di Indonesia, penggunaan fauna makrobentik dalam penilaian kualitas air belum secara optimal dikembangkan dan digunakan secara rutin [9].
Pemantauan Sungai Cisadane dilakukan oleh Pusat sarana Pengendalian Dampak Lingkungan (Pusarpedal) sejak tahun 2000 hingga tahun 2014. Kurun waktu 2000-2001 pemantauan dititik beratkan pada DAS hulu Cisadane untuk mendapatkan daerah acuan (reference site). Kurun waktu 2003-2014 pemantauan dilakukan di sungai utama Cisadane di 15 titik pemantauan [10].

Indikator biologi yang dipantau adalah total bakteri Coliform, jumlah E. coli, parameter ini sesuai dengan lampiran pada Peraturan Pemerintah No. 22 Tahun 2001 sedangkan Chlorofil a dan Bentos atau makrobentik merupakan indikator biologi yang sampai sekarang belum terakomodasi dalam sebuah peraturan kualitas lingkungan di Indonesia terutama kualitas air sungai walaupun indikator biologi tersebut sangat penting manfaatnya. Begitu pentingnya indikator biologi sehingga penelitian ini bertujuan untuk mengkaji karakteristik bioindikator Cisadane melalui pemanfaatan makrobentik untuk menilai kualitas air Sungai Cisadane. Karakterisasi yang terbangun akan mendukung data hasil pemantauan dengan parameter fisika dan kimia yang ada di Sungai Cisadane.

\section{METODOLOGI}

Biomonitoring Makroinvertebrata sungai Cisadane untuk penelitian ini dilakukan pada kurun waktu tahun 2003-2007, 2010 dan 2013 pada bulan Januari, Maret, Juni dan Agustus khususnya stasiun Muara Jaya (C01), Karya Bhakti (C05), Jasmin (C06), Kebon Nanas (C15) dan Kali Baru (C22). Penelitian ini dilakukan berdasarkan pada metodologi kajian terhadap data hasil pemantauan Sungai 
Cisadane yang telah dilakukan pada kurun waktu seperti telah disebutkan terdahulu, Sebagai data pendukung untuk parameter biologi (Makroinvertebrata) adalah parameter kimia yang meliputi: BOD, COD,DO, $\mathrm{NO}_{3}$, TSS. Dari bebarapa stasiun yang mewakili segmen hulu sampai hilir di wilayah administrasi Kota/Kabupaten Bogor dan Kota/Kabupaten Tangerang (Gambar 1).

Pengolahan data biologi dilakukan dengan pendekatan penghitungan Indeks Keanekaragaman (Diversity Indices) dengan menghitung respon komunitas bentos dengan kondisi lingkungan dikombinasikan dengan komponen struktur komunitas yaitu jumlah total individu yang ada di lingkungan (abundance) dalam bentuk Indeks Keanekaragaman Jenis Bentos The ShannonWeiner (H') dan prosentase jumlah kelompok Ephemeroptera, Plecoptera dan Tricoptera (EPT) [8]. Pendekatan lainnya menggunakan indeks biologi (Biotic Indices) yaitu kombinasi kemelimpahan relatif grup taksonomi yang hadir dengan sensitifitas atau toleransi dalam indeks tunggal atau skor, yaitu Average Score Per Taxa (ASPT) [8].

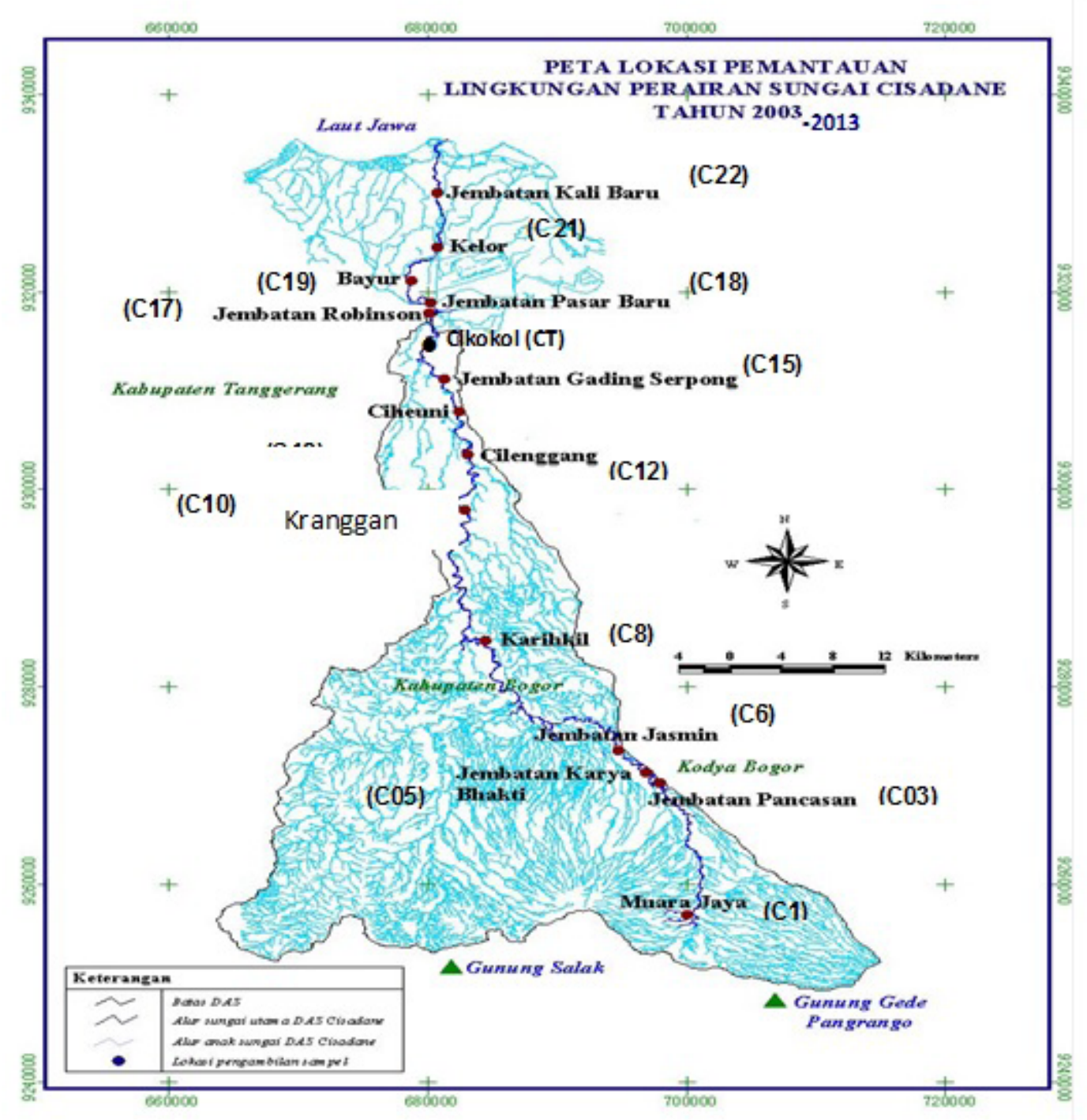

Gambar 1 : Peta stasiun pemantauan Cisadane. 
Pendekatan biomonitoring tradisional menggunakan indeks keanekaragaman untuk menerangkan sebuah komunitas dengan berbagai variasi kondisi lingkungan dikombinasikan dengan tiga (3) struktur komunitas yaitu richness, evenness dan kemelimpahan [8].

Indeks Keanekaragaman Jenis The ShannonWeiner dihitung dengan menghitung jumlah setiap spesies, jumlah masing-masing spesies merupakan jumlah total semua individu yang ada, dan kemudian merangkum hasil kali log dari jumlah masing-masing spesies. Semakin tinggi angka, semakin tinggi keragaman jenis (kemelimpahan). Rumus H' adalah sebagai berikut [11] :

$$
H^{\prime}=-\sum_{i=1}^{s} p_{i} \ln p_{i}
$$

Metode arbitrary dilakukan untuk mengklasifikasikan kualitas air berdasarkan data yang terbentuk di Stasiun pemantauan Sungai Cisadane disebabkan klasifikasi yang ada kurang cocok bila diterapkan di Cisadane.

Analisa air Cisadane berdasarkan parameter kimia meliputi DO, BOD, COD, TSS dan $\mathrm{NO}_{3}$, dengan pengolahan data secara statistik dengan metode Box and Whisker untuk mengetahui kecenderungan.

\section{HASIL DAN PEMBAHASAN}

Penilaian kualitas air menggunakan indikator makroinvertebrata, terutama didasarkan pada keberadaan hewan makrobenthik,seperti larva serangga, cacing, kerang-siput, serta beberapa jenis hewan lunak lainnya yang hidup di dasar perairan.

Hasil perhitungan Indeks Keanekaragaman jenis Bentos The Shannon-Weiner (H') Sungai Cisadane dalam bentuk grafik histogram pada gambar 2 .

Selama tujuh (7) tahun pemantauan menunjukkan bahwa Indeks Keanekaragaman Jenis Bentos( $\left.\mathrm{H}^{\prime}\right)$ menurun ke arah hilir dengan nilai H' $0-0,93$. Nilai H' tertinggi 3,58 di stasiun Jasmin (C06) tahun 2005 dan selama tujuh (7) tahun pemantauan maka stasiun Jasmin (C06) cenderung merupakan stasiun dengan keanekaragaman jenis Bentos tertinggi dengan 8 ordo Bentos jika dibandingkan dengan stasiun pemantauan lainnya termasuk stasiun Muara Jaya (C01) segmen hulu dengan jumlah 6 ordo Bentos. Keanekaragaman jenis Bentos di stasiun Jasmin (C06) dan stasiun Muara Jaya (C01) dapat dilihat pada tabel 1 dan 2.

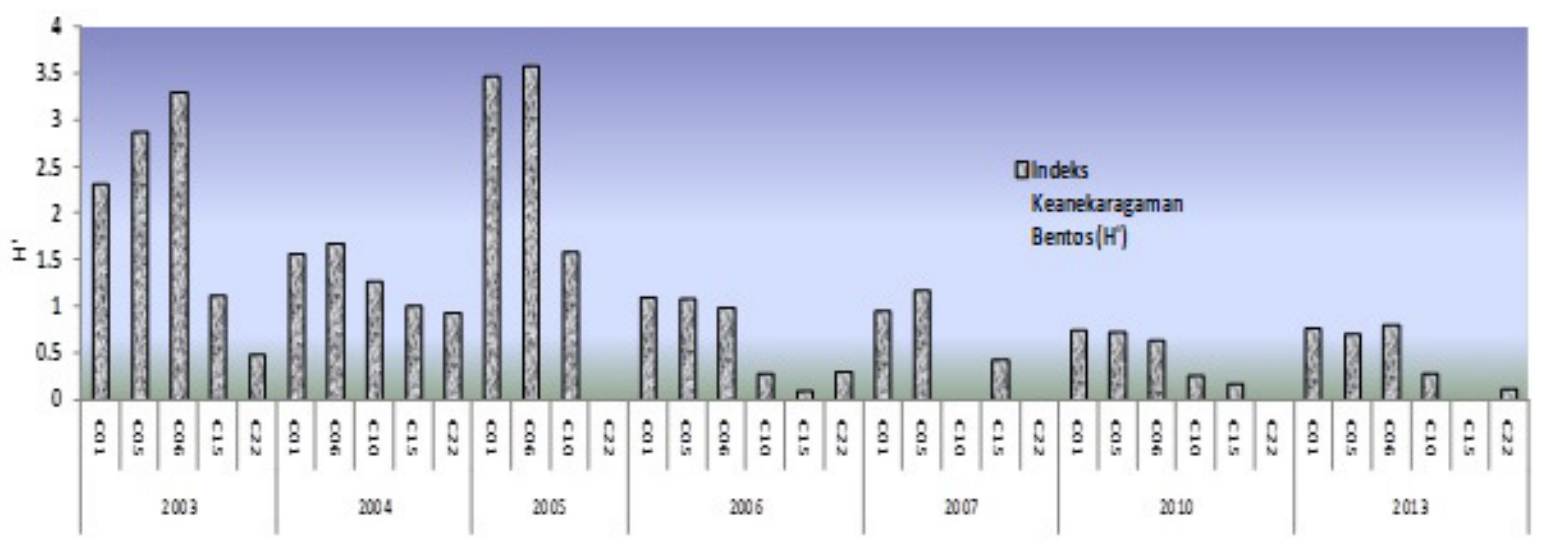

Gambar 2 : Indeks Keanekaragaman (kemelimpahan) Jenis Bentos The Shannon-Weiner (H') di Sungai Cisadane Tahun 2003-2007, 2010 dan 2013 dari hulu ke hilir. 
Tabel 1 : Keanekaragaman jenis Bentos di stasiun Jasmin (C06) tahun 2005 bulan Juni.

\begin{tabular}{|c|c|c|c|c|c|}
\hline No: & Ordo: & Famili: & Genus & Spésiess & $\mathbf{N}$ \\
\hline \multirow[t]{4}{*}{1} & Ephemeroptera & Baetidae & Baetis & B. niger & 37 \\
\hline & & Leptophlebidae & Paraleptoplebia & P. submarginata & 9 \\
\hline & & & & P. cinca & 8 \\
\hline & & & & C. rivolorum & 10 \\
\hline \multirow[t]{5}{*}{2} & Trichoptera & Hydropsychidae & Hydropsyche & H. Siltalai & 46 \\
\hline & & & & H. anguistipennis & 50 \\
\hline & & & & H. intabilis & 14 \\
\hline & & & & H. contubernalis & 14 \\
\hline & & & & H. pellucidula & 8 \\
\hline 3 & Coleoptera & Elmidae & Notriolus & N. maculata & 20 \\
\hline \multirow[t]{2}{*}{4} & Diptera & Chironomidae & Chironomus & Chironomus sp. & 56 \\
\hline & & Tanypodinae & - & - & 6 \\
\hline 5 & Oligochaeta & Haplotaxidae & - & - & 10 \\
\hline \multirow[t]{2}{*}{6} & Prossobranchiata & Viviparidae & Viviparus & Viviparus sp. & 6 \\
\hline & & Thiaridae & Thiara & T. balanensis & 5 \\
\hline 7 & Hirudonea & Erpobdellidae & Erpobdella sp. & Erpobdella & 11 \\
\hline 8 & Decapoda & Sundhathelphusidae & - & - & 2 \\
\hline
\end{tabular}

Keterangan : $\mathrm{N}=$ Jumlah species Bentos

Jenis Bentos yang mendominasi di stasiun Muara Jaya adalah Ordo Ephemeroptera dari Familia Leptophlebidae, dan masih diketemukan Ordo Coleoptera, familia Psephenidae. Kelompok organisme ini sangat sensitif terhadap pollutan (Grup I). Setiap ordo dari binatang yang diketemukan diberikan nilai indeks 10 - 7. Apabila suatu lokasi didominasi oleh Bentos atau makroinvertebrata ini maka kualitas air di lokasi ini adalah bagus, kelompok organisme sensitif ini adalah [12]: indikator ini antara lain melalui teknik empiris. Teknik ini mengkatagorikan kualitas air berdasarkan kemelimpahan taxa (taxa richness) dari Ephemeroptera, Plecoptera, Tricoptera (EPT), kelompok organisme ini merupakan kelompok organisme sensitif [12]. Nilai EPT yang tinggi untuk katagori perairan alami (bersih) dan nilai EPT yang rendah untuk katagori perairan yang telah tercemar. Kemelimpahan taxa EPT merupakan nilai toleransi yang menunjukkan tidak hanya

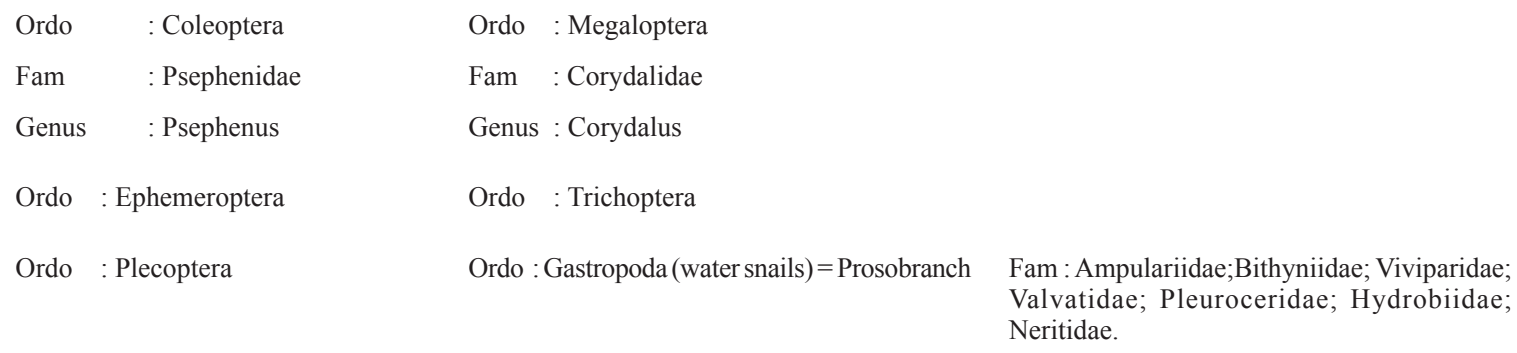

Karena sifat sensitifnya terhadap pencemaran maka makroinvertebrata perairan biasa digunakan sebagai organisme indikator. Beberapa teknik telah digunakan untuk menghasilkan nilai toleransi organisme respon terhadap keberadaan polutan organik tetapi juga respon terhadap adanya tekanan atau gangguan $[13,14]$. 
Tabel 2 : Keanekaragaman jenis Bentos di stasiun Muara Jaya (C01) tahun 2005 bulan Juni.

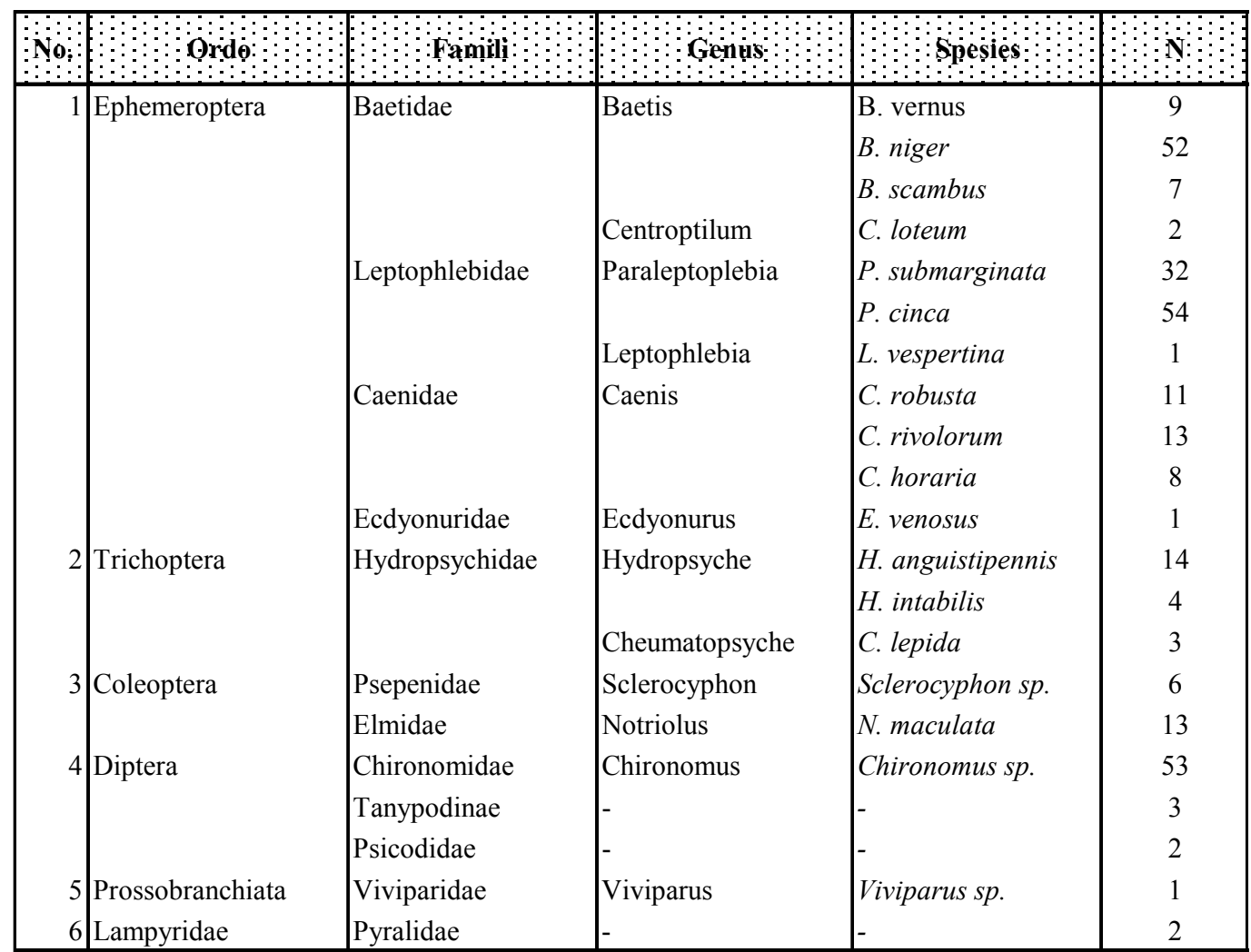

Nilai prosentase EPT di stasiun Muara Jaya (C01) Tahun 2005 sebesar 77,57\% dan jumlah ini mendominasi keanekaragaman Bentos di stasiun Muara Jaya (C01). Walau pun begitu diketemukannya Ordo Coleoptera-familia Elmidae dan Ordo Diptera di stasiun Muara Jaya (C01) mengindikasikan bahwa stasiun Muara Jaya sudah tidak dapat dikatagorikan dalam perairan yang bersih tetapi termasuk dalam perairan yang sudah tercemar atau telah mendapat gangguan. Karena kelompok

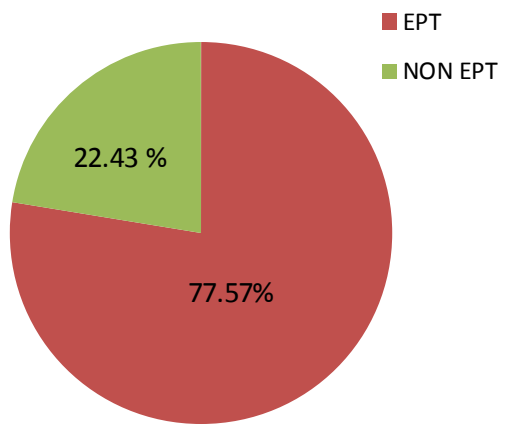

Gambar 3 : Prosentase taxa EPT di stasiun Muara Jaya (C01) organisme ini memiliki rentang toleransi terhadap polutan yang cukup lebar [12].

Pada stasiun Jasmin (C06) tahun 2005 nilai prosentase EPT sebesar $67,12 \%$, di stasiun ini ditemukan kelompok organisme toleran terhadap polutan yaitu kelompok dari Class Hirudinea dan Class Olligochaeta. Adanya kelompok ini mengindikasikan suatu perairan telah mengalami gangguan dan masuk katagori perairan berkualitas buruk [12].

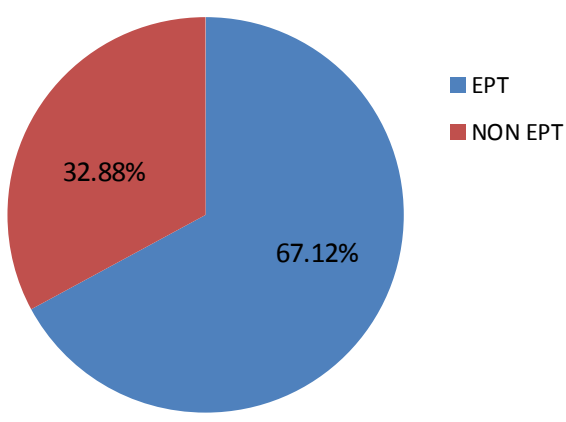

Gambar 4 : Prosentase taxa EPT di stasiun Jasmin (C06). 
Taxa Pollution-Intermediate Organisms (Group II). Adanya organisme ini kualitas air tidak dapat digolongkan ke dalam kualitas air yang bersih karena rentang toleransi kelompok organisme ini sangat lebar. Kelompok organisme ini adalah [12] :

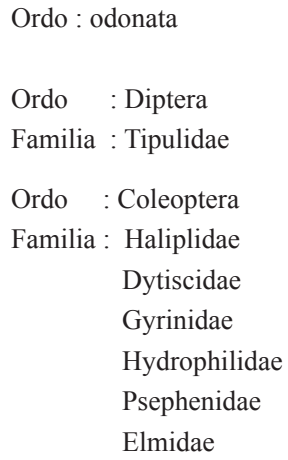

Taxa Pollution-Insensitive Organisms (Group III). Adanya organisme ini kualitas air dapat digolongkan ke dalam kualitas air yang buruk. Karena kelompok organisme ini sangat toleran terhadap pencemaran. Kelompok organisme ini adalah [12] :

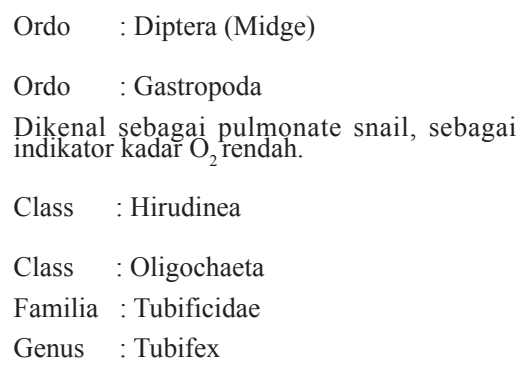

Keanekaragaman jenis Bentos Cisadane dari hulu ke hilir dari tahun 2003 sampai 2013 menurun. Stasiun Kali Baru (C22) memiliki indeks keanekaragaman jenis (H') sebesar 0,12 dan didominasi oleh jenis dalam class Oligochaeta dari familia Haplotaxidae. Dominasi dari class Oligochaeta mengindikasikan bahwa kualitas perairan di stasiun ini tergolong buruk [13]. Berdasarkan

Tabel 3 : Klasifikasi kualitas air S. Cisadane berdasarkan nilai ASPT dengan metode arbitary.

\begin{tabular}{|c|l|l|l|}
\hline Klasifikasi & Warna & Rentang Nilai ASPT & Kualitas \\
\hline 1 & & $0,0-5,8$ & Buruk \\
2 & & $5,8-6,9$ & Sedang \\
3 & & $7,0-8,5$ & Sedikit tercemar \\
4 & & $8,6-10$ & Baik \\
\hline
\end{tabular}




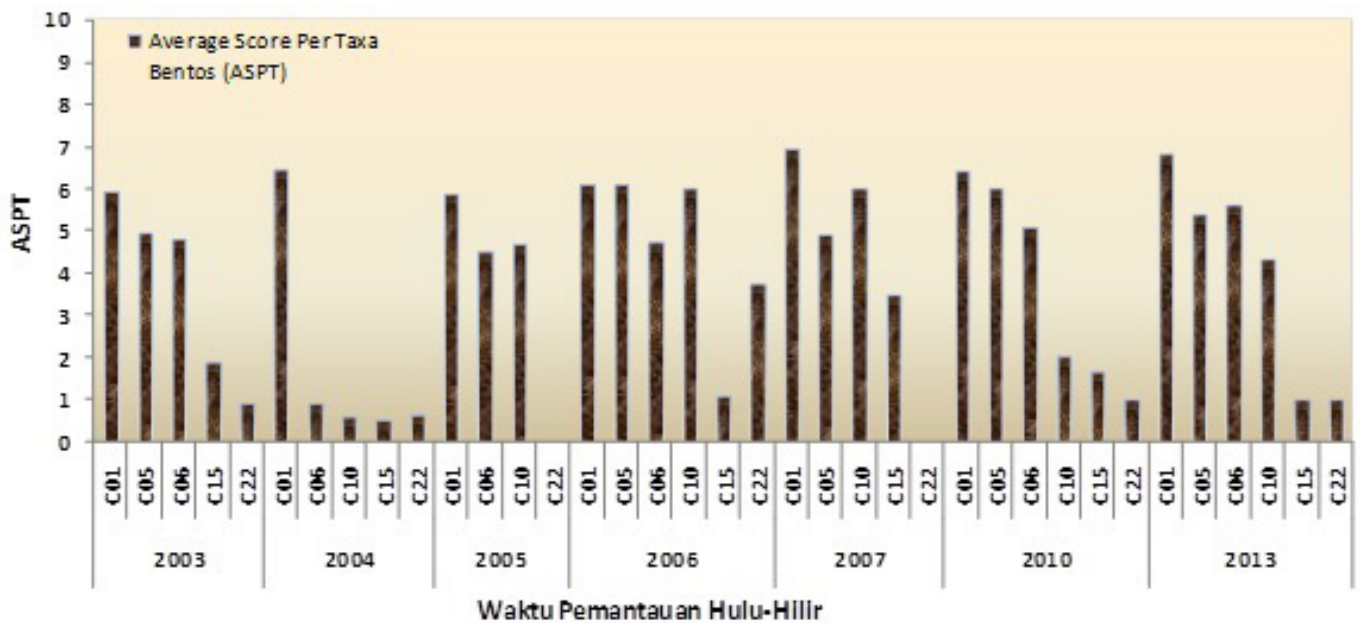

Gambar 5 : Data Average Score Per Taxa (ASPT) Cisadane tahun 2003-2007,2010 dan 2013 dan pengelompokan kualitas lingkungan air.

Klasifikasi kualitas air berdasarkan nilai ASPT Wright et al. (1993) tidak bisa diterapkan di Cisadane karena nilai ASPT di Cisadane jauh lebih tinggi sehingga dibuat metode klasifikasi sendiri seperti tercantum pada Tabel 3. Nilai ASPT yang tinggi merupakan informasi bahwa keanekaragaman bentos di Indonesia khususnya Cisadane lebih tinggi bila dibandingkan di Negara lain misalnya : Nigeria khususnya sungai Challawa [14]. Sebagai perbandingan di bawah ini disajikan tabel dari Wright et al. (1993) yang dipakai untuk menilai kualitas Sungai Challawa di Nigeria (Tabel 4).

Berdasarkan klasifikasi kualitas air Sungai Cisadane pada Tabel 3 maka kualitas air Sungai Cisadane dari hulu sampai hilir berada pada rentang kualitas sedang sampai kualitas buruk.

Tabel 4 : Hasil penilaian kualitas Sungai Challawa berdasarkan Wright et al. (1993).

\begin{tabular}{|c|c|c|c|c|c|c|c|c|c|c|}
\hline \multirow{2}{*}{ No. } & \multirow{2}{*}{ Ttk } & \multirow{2}{*}{$\mathbf{N}$} & \multirow{2}{*}{$\sum_{\text {BMWP }}^{\Sigma}$} & \multirow{2}{*}{ ASPT } & \multirow{2}{*}{ Kls } & \multirow{2}{*}{ Ket. } & \multicolumn{4}{|c|}{ Tabel Wright et al. (1993) } \\
\hline & & & & & & & Ttk & ASPT & Kls. Biologi & Ket \\
\hline 1 & A & 63 & 53 & 0,84 & B & Baik & A & $\geq 0,89$ & $A$ & Sangat Baik \\
\hline 2 & B & 37 & 44 & 1,19 & A & Sangat Baik & B & $0,77-0,88$ & B & Baik \\
\hline 3 & C & 51 & 28 & 0,55 & D & Buruk & C & $0,66-0,76$ & C & Sedang \\
\hline 4 & $\mathrm{D}$ & 67 & 58 & 0,87 & B & Baik & $\mathrm{D}$ & $<0,66$ & D & Buruk \\
\hline
\end{tabular}


(a)

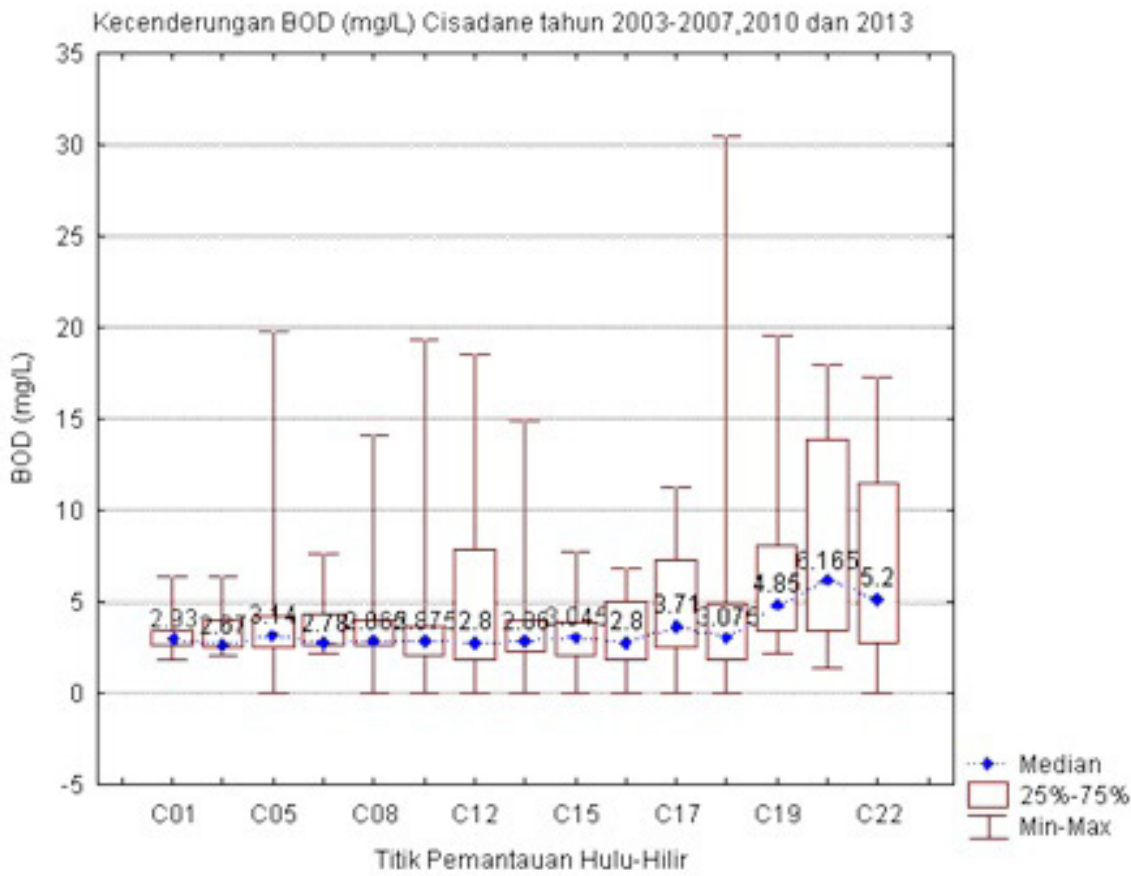

(b)

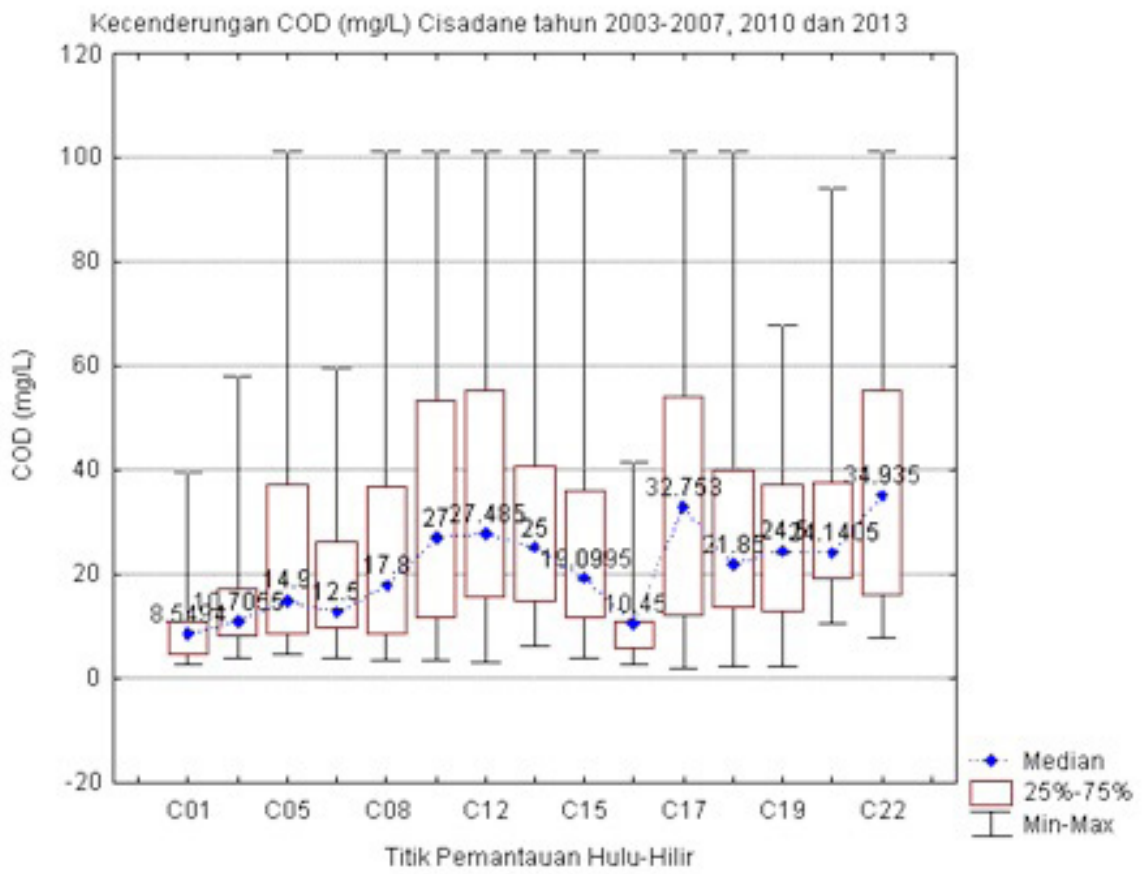


(c)

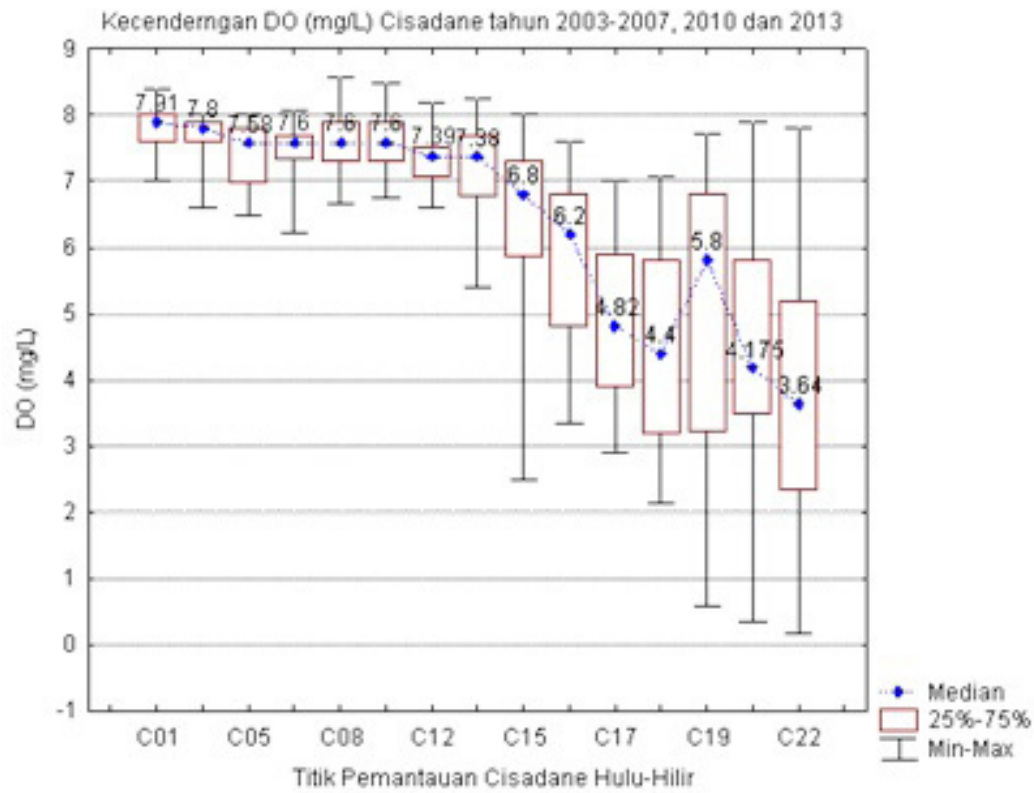

(d)

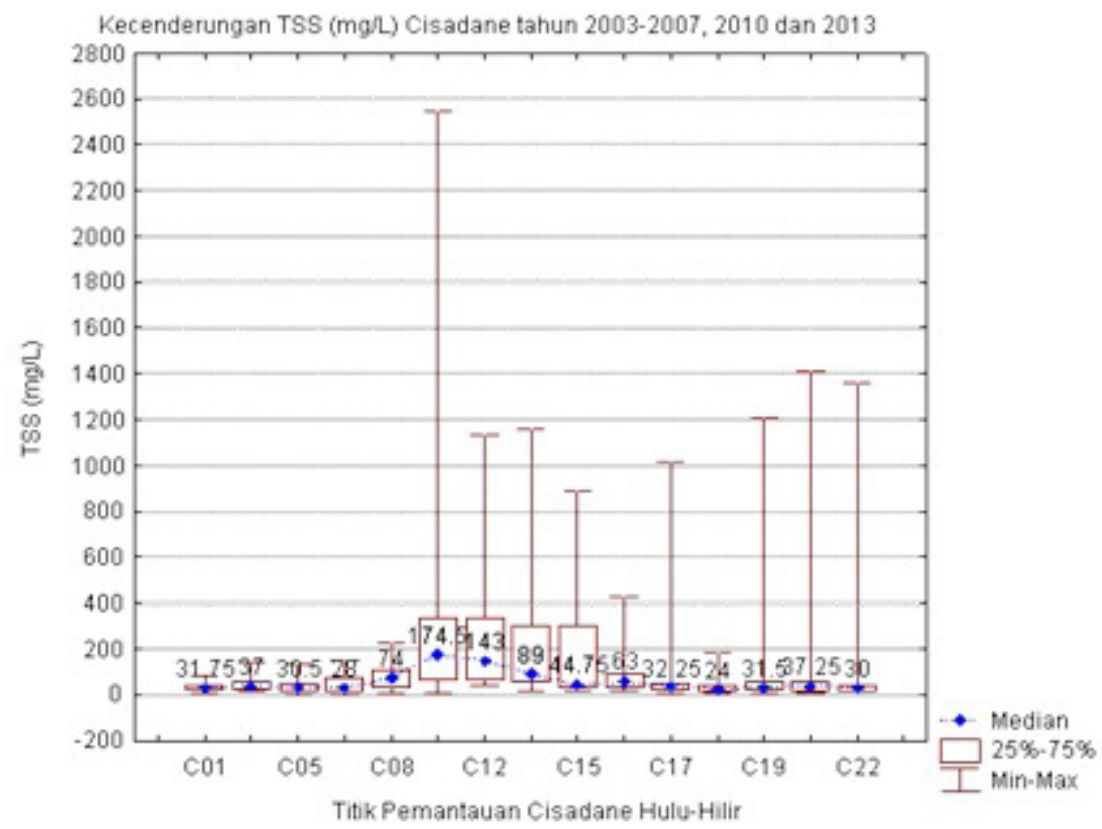

Gambar 6 (a,b,c dan d) : Kecenderungan kualitas air Sungai Cisadane berdasarkan parameter kimia DO,COD,BOD dan TSS tahun 2003-2007; 2010 dan 2013. 
Data kimia yang mendukung kualitas Sungai Cisadane tertera pada gambar 6 dengan kecenderungan kualitas sedang sampai buruk.

Distribusi dan kemelimpahan Bentos atau makroinvertebrata tidak hanya dipengaruhi oleh kualitas air, tetapi juga oleh faktor lain seperti : kecepatan arus, jenis substrat (karakteristik sedimen), dan kemelimpahan vegetasi air. Distribusi dan kemelimpahan makroinvertebrata dipengaruhi oleh faktor biotik dan abiotik. Faktor biotik yang mempengaruhi kelimpahan makroinvertebrata adalah hubungan saling interaksi antar organisme atau hubungan tropik memangsa dan dimangsa. Faktor abiotik yang mempengaruhi kelimpahan Bentos antara lain jenis substrat,sedimen, konsentrasi oksigen, fluktuasi musim, sumber makanan, kemelimpahan vegetasi. Berdasarkan penelitian bahwa komposisi dan kemelimpahan Bentos atau makroinvertebrata relatif stabil dari satu tahun ke tahun berikutnya di dalam sistem yang tidak ada gangguan [15].

\section{UCAPAN TERIMAKASIH}

Ucapan terimakasih kepada Epha Deswarni teknisi Laboratorium Biologi Pusarpedal atas dedikasi dan kerjasama yang baik selama penelitian berlangsung.

\section{SIMPULAN}

1. Ordo Ephemeroptera, Familia Le pthophlebidae, Genus Paraleptoplebia, Spesies P. submarginata dan P. cinca merupakan bioindikator yang mencirikan daerah hulu Sungai Cisadane.
2. Ordo Ephemeroptera, Familia Baetidae, Genus Baetis, Spesies B. Niger.

3. Ordo Trichoptera, Familia Hydropsychidae, Genus Hydropsyche, Spesies H. Siltalai dan H. anguistipennis merupakan bioindikator yang mencirikan daerah dengan gangguan dominan dari pencemar domestik di Sungai Cisadane (daerah tengah).

4. Class Oligochaeta, Familia Haplotaxidae dan Cacing Tubifisidae merupakan bioindikator yang mencirikan daerah hilir di Sungai Cisadane.

5. Kualitas air Sungai Cisadane dari hulu sampai hilir berdasarkan bioindikator Bentos makroinvertebrata berada pada status tercemar sedang sampai buruk.

6. Prosen (\%) EPT menurun dari hulu menuju hilir di Sungai Cisadane.

7. Kualitas Sungai Cisadane diklasifikasikan menjadi 4 berdasarkan nilai ASPT yaitu : buruk (0.0-5.8), sedang (5.8-6.9, sedikit tercemar (7.08.5) dan baik (8.6-10).

\section{DAFTAR PUSTAKA}

(1) Wowor D. Studi Biota Perairan dan Herpetofauna di Daerah Aliran Sungai (DAS) Ciliwung Dan Cisadane: Kajian Hilangnya Keanekaragaman Hayati. Laporan Akhir Program Insentif Penelitian Dan Perekayasa LIPI 2010;p.11,22.

(2) Agustiningsih D, Sasongko SB, Sudarno. Analisis Kualitas Air Dan Strategi Pengendalian Pencemaran Air Sungai Blukar Kabupaten Kendal. Jurnal Presipitasi 2012 September; 9(2):64-65. 
(3) Siahaan R,Indrawan A,Soedharma D, Prasetya LB. Kualitas Air Sungai Cisadane, Jawa BaratBanten. Jurnal Ilmiah Sains 2011 Oktober;11(2):268,271,272.

(4) Isnaini A. Penilaian Kualitas Air dan Kajian Potensi Situ Salam Sebagai Wisata Air Universitas Indonesai,Depok. FMIPA Universitas Indonesia, Skripsi 2011 Juni.

(5) Wulandari D. Keterkaitan Antara kelimpahan Fitoplankton Dengan Parameter Fisika Kimia Di Estuari Sungai Brantas (Porong), Jawa Timur. Fakultas Perikanan Dan Ilmu Kelautan, Institut Pertanian Bogor, Tesis 2009.

(6) Thampy Jayakumaran, Raja M, Thambiratnam Sivaruban and Arunachalam M. Application of Rapid Bioassessment in selected stream of the Western Ghats using Benthic Macroinvertebrates. International Journal of Environmental Biology. Tamil Nadu, India 2013 October;3(4): 173

(7) Li L et.al. Biomonitoring and Bioindicator Used for River Ecosystem: Definition, Aproaches and Trends. Procedia Enviromental Sciences 2. Elsevier Ltd. (2010)

(8) Sudarso Y, Suryono T, Yoga GP. Penyusunan Biokriteria dengan menggunakan Konsep Multimetrik: Studi Kasus Anak Sungai Cisadane. Jurnal Oseanologi Dan Limnologi Di Indonesia 2009 Agustus; 35(2):180181.

(9) Boonsoong B, Sangpradub N, Barbour MT, Simachaya W. An Implementation Plan For Using Biological Indicator To Improve Of Water Quality In Thailand. Journal Environ Monit
Assess 2010 165:205

(10) Nolan K.A and Callahan JE.Beachcomber biology: The Shannon-Weiner Species Diversity Index.St. Francis College Brooklyn NY, ABLE 2005 Proceedings Vol.27.

(11) Rock.geo.esuohio.edu/norp/bmil.htm/ diakses tanggal 13 Oktober 2014

(12) Pelletier MC, Gold AJ, Helshe JF, Buffum HW. Ecological Indicator: A method to identify estuarine macroinvertebrate pollutan indicator species in the Virginian Biogeographic Province. Elsevier Ltd 2010 September; 10(5); 1038;1044.

(13) Keci E,Paparisto A, Pepa B, Xhaxhiu K. Use Of Benthic Macro-Invertebrate Taxones as Biological Indicatorsnin Assessing Water Quality of Erzeni River, Albania, During 2011-2012. IJBAS-IJENS 2012;12(06); 165

(14) Suleiman, K and Abdullahi,I.L. Biological Assessment Of Water Quality: A Study Of Challawa River Water Kano,Nigeria. Bayero Journal of Pure and Applied Sciences, 2011 December; 4(2):125-126.

(15) Shimabukuro EM, Henry R. Controlling factors of benthic macroinvertebrates distribution in a small tropical pond, lateral to the Paranapanema River (Sao Paulo, Brazil). Acta Limnol. Bras. Rio Claro 2011 June; 23(2). 